\title{
UM BRASIL MAXIXE: REPRESENTAÇÕES CULTURAIS E IDENTITÁRIAS EM COMPOSIÇÕES DESSE GÊNERO MUSICAL
}

\author{
Débora Bender ${ }^{1}$ \\ Juracy Assmann Saraiva ${ }^{2}$
}

Compreender a formação de um povo é uma tarefa complexa, que exige análises minuciosas para que o estudioso não corra o risco de atribuir a uma nação representações unívocas, com base em estereótipos, que são estendidos a todos os seus habitantes. O mito da convergência harmônica das três raças, que tentou explicar, na virada do século XIX para o século XX, a composição do povo brasileiro, é um estereótipo que deixou resquícios no imagético nacional e estrangeiro a respeito do Brasil, até os dias atuais. Essa forma de concepção da identidade nacional brasileira ignora a pluralidade de sua formação cultural e os processos de assimilação e tradução, por vezes conflituosos, que se configuraram ao longo do tempo, dando ao país identidades singulares, que mostram a diversidade, integrada à unicidade.

De acordo com Ortiz (2006), a teoria de integração das raças tornou-se plausível devido ao desenvolvimento dos grandes centros urbanos, nos quais surgiu a classe proletária, formada, em sua maioria, por mestiços e negros libertos, que passaram a trabalhar na indústria e adquiriram uma expressiva representatividade na vida social do Brasil. A formação dessa classe de trabalhadores foi uma das consequências das mudanças estruturais de caráter econômico, social e político, que ocorreram nos três últimos últimos decênios do século XIX, entre as quais se destacam a abolição do trabalho escravo, o ingresso de imigrantes italianos e alemães, a alteração das relações de trabalho e a expansão do trabalho remunerado.

O maxixe, que pode ser considerado, de acordo com os estudiosos da música, “o primeiro ritmo brasileiro", constitui-se paralelamente a essas mudanças estruturais, que antecedem, em alguns anos, o desenvolvimento da "teoria das três raças". Assim, o ritmo pode ser concebido como resultado da formação das cidades, em que, de certa forma, as camadas mais populares começaram a se integrar à sociedade brasileira, e

\footnotetext{
${ }^{1}$ Universidade Feevale, Brasil.

${ }^{2}$ Universidade Feevale, Brasil.
} 
como fruto da articulação de cadências europeias e africanas, ou seja, da influência recíproca de raças diferentes.

Sob esse ângulo, o artigo analisa representações culturais e indentitárias brasileiras, presentes em letras de quatros maxixes, cujo sucesso, no Brasil, foi inquestionável, e se efetiva por meio da exposição e discussão da influência do mito das três raças na formação da identidade nacional; por uma breve contextualização do surgimento do maxixe e pela correlação da letra dos quatro maxixes com o cenário cultural brasileiro da época em que foram lançados.

\section{O “mito das três raças" e sua influência na formação da identidade nacional}

Várias foram as tentativas de compreender e conceber a complexa cultura brasileira, dilema que ainda persiste entre os estudiosos contemporâneos. As representações acerca do Brasil foram e continuam tão diversas quanto os estudos que se propõem a investigá-las. A busca pela definição de uma identidade nacional teve evidência, no século XIX, devido aos estudos produzidos por brasileiros os quais se distinguiam dos efetivados nos três primeiros séculos após o descobrimento do Brasil, quando o país foi avaliado e "engendrado" pelos colonizadores europeus a partir concepções pré-estabelecidas sobre o Novo Mundo:

\footnotetext{
Pode-se dizer que a América foi sendo desenhada e descrita por pensadores, artistas, navegadores e autores, durante um longo processo de conhecimento e estabelecimento de identidades. Nesse diálogo entre Novo e Velho Mundo, predominou evidentemente um sentido europeu, revestido de forte ideologia de dominação (BIGNAMI, 2005: 79).
}

Sob esse ângulo, as primeiras representações sobre o Brasil, presentes em relatos de colonizadores e viajantes, restringiram-se à caracterização da natureza exuberante e dos curiosos e exóticos costumes indígenas, como o de andarem nus "sem coisa alguma que lhes cobrisse suas vergonhas", conforme o relato de Pero Vaz de Caminha, escrivão-mor da frota do capitão Pedro Álvares Cabral, responsável pelo "descobrimento"” do Brasil. Além disso, a "ideologia da dominação", mencionada na

\footnotetext{
${ }^{3}$ Questiona-se o termo "descobrimento" quando relacionado à chegada dos portugueses ao Brasil, uma vez que as terras brasileiras já eram habitadas, não sendo possível, portanto, descobri-las. A aceitação e o uso desse termo durante muitos anos podem ser explicados pela primazia do ponto de vista etnocêntrico europeu, cuja visão permeava os estudos históricos.
} 
citação, "assegurou" aos europeus o direito de invalidar as práticas culturais dos nativos para lhes impor um "processo civilizatório".

Nos séculos seguintes, o Brasil foi projetado pelos europeus como uma colônia que absorvia a cultura dos europeus, considerada superior, buscando imitá-la. De acordo com Sérgio Buarque de Holanda (1995), o Brasil não ficou imune às manifestações dos seus colonizadores, ainda que Portugal também tivesse sido influenciado pelos habitantes das terras de Pindorama. Assim, por um lado, a colônia recebeu uma vasta herança dos portugueses, cujos traços impregnam a constituição da cultura brasileira e nela se refratam: a fraqueza das formas de organização que requerem solidariedade e ordenação entre seus membros; a imposição de regras pela força; o predomínio de privilégios hereditários; a frouxidão da estrutura social; a repulsa à moral fundada no culto ao trabalho. Por outro lado, os portugueses também incorporaram hábitos indígenas que eles consideraram "dignos" de serem introduzidos em seu modo de vida, como o banho, o descanso na rede, a inclusão da farinha de mandioca na culinária, entre outros. O sociólogo conclui que "a tentativa de implantação [pelos portugueses] da cultura europeia em extenso território, dotado de condições naturais, se não adversas, largamente estranhas à sua tradição milenar, é, nas origens da sociedade brasileira, o fato dominante e mais rico em consequências (BUARQUE DE HOLANDA, 1995: 31)".

Também foram os portugueses os responsáveis por implantar o sistema escravagista, que, por muito tempo, sustentou a exploração latifundiária e a monocultura no Brasil. De acordo com Buarque de Holanda (1995), o uso da mão-de-obra escrava relacionava-se à pouca disposição para o trabalho por parte dos lusitanos:

Uma digna ociosidade sempre pareceu mais excelente, e até mais nobilitante, a um bom português, ou a um espanhol, do que a luta insana pelo pão de cada dia. O que ambos admiram como ideal é uma vida de grande senhor, exclusiva de qualquer esforço, de qualquer preocupação (BUARQUE DE HOLANDA, 1995: 38).

Apesar de destinar ao negro um lugar ínfimo na sociedade, a "ausência de qualquer orgulho de raça" (BUARQUE DE HOLANDA, 1995: 53) por parte dos portugueses, possibilitou a miscigenação no país, a qual deu origem ao povo brasileiro. O cruzamento racial já era característico da sociedade portuguesa antes mesmo de sua chegada ao Brasil, uma vez que as grandes navegações já haviam sido responsáveis por levarem indivíduos de raças e de etnias distintas à metrópole portuguesa. 
Consequentemente, a convivência entre brancos, negros, índios favoreceu a miscigenação e foi a base para tentar compreender o processo de formação da identidade brasileira. Essa, na segunda metade do século XIX, foi enfocada pela intelectualidade nacional a partir das teorias em voga - o Positivismo de Comte, o darwinismo de Darwin, o evolucionismo de Spencer - as quais possibilitavam recompor a história das sociedades humanas e, no caso do Brasil, justificar a correlação entre as condições do país com as noções de raça e meio. Esses dois parâmetros fundamentaram a interpretação da história brasileira e estabeleceram a distinção em relação à cultura europeia, já que o Brasil se diferenciava geograficamente da Europa e era povoado por uma raça diferente da que se situava no Velho Continente (ORTIZ, 2006).

Referindo-se à teoria racial, que atribuía à mistura de raças, ou seja, à mestiçagem, o atraso no desenvolvimento da sociedade brasileira, Renato Ortiz (2006), afirma que ela se alicerça na ideia da "superioridade" da civilização europeia, ideia que inferiorizava o negro e o índio em relação ao branco. Roberto Damatta (1986) ressalta que "o problema maior dessas doutrinas, o horror que declaravam, era, isso sim, contra a mistura ou miscigenação de "raças"” (DAMATTA, 1986: 38). Essa teoria, apesar de sua base racista, teve papel importante nas definições a respeito do Brasil e em questões históricas e sociais.

Com efeito, com o intuito de esconder a injustiça social contra negros, índios e mulatos, um argumento de natureza biológica passou a encobrir o problema do preconceito racial da sociedade brasileira. Damatta (1996) denomina essa concepção de a "fábula das três raças": o Brasil seria supostamente formado por um triângulo de raças, o que nos conduziria ao mito da democracia racial. Contudo, essa democracia era inerente a uma sociedade hierarquizada, em que alguns indivíduos eram superiores aos outros. Por meio desse discurso, criava-se a falsa ideia de que, no Brasil, não havia preconceito racial, cujo encobrimento leva o autor a usar o termo "racismo à brasileira".

Entretanto, o mito da igualdade das raças não é plausível, uma vez "os fatos concretos" o desmentem, visto que o negro ocupa um lugar inferior na sociedade brasileira. Dessa forma, "o mito das três raças não consegue [...] se ritualizar, pois as condições materiais para a sua existência são puramente simbólicas. Ele é linguagem e, não, celebração"4 (ORTIZ, 2006: 39).

\footnotetext{
4 Segundo Ortiz (2006), exemplo da dificuldade de "concretização do mito das três raças" e da interpretação do brasileiro pode ser encontrado na obra $O$ cortiço, de Aluísio Azevedo, lançado em 1890,
} 
No início do século XX, o processo de urbanização e de industrialização favorece o surgimento de uma classe média, de um proletariado urbano, que conduz a mudanças significativas na sociedade brasileira. Nesse contexto, a teoria das três raças sofre uma transformação: a mestiçagem, que antes era considerada a responsável pelo atraso no desenvolvimento brasileiro, trona-se positiva e indispensável para a compreensão da formação identitária brasileira, e "permite completar definitivamente os contornos de uma identidade que há muito vinha sendo desenhada" (ORTIZ, 2006: 41).

Ortiz (2006) destaca que Gilberto Freyre, em sua obra Casa Grande Senzala, publicada em 1933, aborda a temática da mestiçagem não mais em termos raciais, mas como aspecto cultural:

O mito das três raças torna-se então plausível e pode se atualizar como ritual. A ideologia da mestiçagem, que estava aprisionada nas ambiguidades das teorias racistas, ao ser reelaborada pode difundir-se socialmente e se tornar senso comum, ritualmente celebrado nas relações do cotidiano, ou nos grandes eventos como carnaval e o futebol. O que era mestiço torna-se nacional (ORTIZ, 2006: 41).

Dessa forma, na virada do século XIX para o século XX, a temática da convergência de raças passou a ser importante para a criação de uma identidade nacional para o Brasil e vigorou durante todo o século XX, sendo enfatizada e reforçada na década de 1920, pelo movimento modernista, que tentava inserir o Brasil no contexto das transformações mundiais e valorizar as manifestações autóctones da cultura brasileira, até então influenciada pela europeia.

Sob essa perspectiva, o samba, que é considerado genuinamente brasileiro e pressupõe um momento de harmonização e celebração das etnias que compõem o país ${ }^{5}$, serve de exemplo da natureza positiva da mestiçagem. Entretanto, o samba, tal qual é hoje conhecido, descende do maxixe, um ritmo que acompanhou a mudança de concepção relativa à mestiçagem brasileira, da qual ele próprio é resultado.

\section{O maxixe como reflexo da miscigenação brasileira}

uma vez que não há efetivamente "uma mistura" das características europeias e "brasileiras" na composição das personagens e, sim, personagens que se transformam e mantém os traços característicos de uma raça.

${ }^{5}$ Embora o povo brasileiro seja reconhecido por meio desse ritmo e do rito do carnaval, essa celebração e aparente "harmonia" encobre conflitos raciais muito sérios ainda presentes na nossa sociedade. 
Na década de 1870, após um período de predominância da música erudita e da dança de origem europeia, constituiu-se o maxixe, evento que, segundo Tinhorão (2013), "marca o advento da primeira grande contribuição das camadas populares do Rio de Janeiro à música no Brasil” (TINHORÃO, 2013: 71). Esse gênero, como também o tango brasileiro e o choro, resultou de uma nacionalização que as danças importadas sofreram ao serem fundidas a formas de origem africana, as quais eram denominadas de "batuque" (SEVERIANO, 2008: 28):

\begin{abstract}
Nascido da maneira livre de dançar os gêneros de música em voga na época principalmente a polca, a schottisch e a mazurca -, o maxixe resultou do esforço dos músicos de choro em adaptar o ritmo das músicas à tendência aos volteios e requebros de corpo com que os mestiços, negros e brancos do povo teimavam em complicar os passos da dança de salão (TINHORÃO, 2013: 71).
\end{abstract}

Além dessa adaptação dos ritmos europeus a características da cultura africana, o uso dos instrumentos também foi "abrasileirado", uma vez que houve modificações na “técnica de execução do violão, do cavaquinho e do próprio piano. Dessa modificação, resultaram, principalmente, três gêneros: o choro, o maxixe e o tango brasileiro, que têm como traço em comum "o ritmo binário e a utilização da síncope ${ }^{6}$ afro-brasileira, além da presença da polca na sua gênese" (SEVERIANO, 2008: 28).

O choro teve origem nos grupos de músicos denominados "chorões", cuja alcunha remetia ao tipo de som que produziam: "um solo acompanhado de contracanto e modulações", que descendia da chamada "música de senzala". Essa variedade de música era produzida por pequenas bandas formadas por negros escravos, que, com o aval de seus senhores, transmitiam seu estilo aos "grupos brancos e mestiços da baixa classe média urbana, pequenos funcionários públicos, músicos de bandas militares e burocratas" (TINHORÃO, 2013: 74). Ao tocar para diferentes públicos, as bandas atentavam para o tipo de som que produziam: quando eram convidadas a tocar em casas de família "mais respeitáveis", os sons produzidos (polcas, valsas, mazurcas) eram mais "contidos", ou seja, "muito próximos da execução que tinham à vista das partituras, nos salões onde imperavam os pianos" (TINHORÃO, 2013: 75). Por outro lado, quando tocavam em algum lugar popular ou no bairro Cidade Nova, considerado o mais pobre e o mais populoso da cidade de acordo com recenseamento de 1872, a interpretação da

\footnotetext{
${ }^{6} \mathrm{O}$ termo "síncope" se refere a um recurso rítmico de origem africana que se caracteriza pela conjunção de uma semicolcheia/colcheia/semicolcheia, que foi transferido, no século XIX, para a métrica binária europeia, em sua forma original. CANÇADO, 2000:6.
} 
banda era diferente, sugerindo, com seu ritmo e melodia, movimentos mais livres e sensuais. Tinhorão, o estudioso de história da música, relata que

Quando a novidade da dança de par permitiu o enlaçamento dos corpos, a tendência dos bailarinos foi a de estilizar esses movimentos através da criação de uma série de passos mais tarde conhecidos por nomes como cobrinha, parafuso, balão caindo e corta capim, todos bastante expressivos para darem ideia de quão coleante, remexido, balouçante e ágil de pés viria a ser o maxixe (TINHORÃO, 2013: 76).

Consequentemente, o maxixe descende do choro carioca, sendo resultado da associação de um ritmo europeu com o de manifestações musicais das camadas mais baixas da população do Rio de Janeiro. A origem do maxixe está, pois, relacionada à “descida das polcas dos pianos dos salões para a música dos choros, à base de flauta, violão e oficlide ${ }^{7, "}$ (TINHORÃO, 2013: 74), e seu aparecimento decorreu do gosto das camadas populares, que apreciavam um ritmo com movimentos mais sensuais e livres.

Entretanto, o gênero não ficou restrito à periferia carioca: as demais classes sociais conheceram a nova composição musical nos "bailes das sociedades carnavalescas e nos quadros de canto e dança do teatro de revista ${ }^{8}$ " (TINHORÃO, 2013: 78). Os clubes carnavalescos eram associações criadas por comerciantes com o intuito de promover eventos em que as pessoas pudessem dançar e se divertir e seu surgimento relaciona-se com a "ampliação da vida urbana carioca", que promoveu o afrouxamento do "rígido esquema de vida patriarcal", permitindo que os homens se divertissem "fora do âmbito familiar". (TINHORÃO, 2013: 79).

Em função dos preconceitos vigentes da época, "as moças e mulheres de família", não podiam frequentar esses clubes. Dessa maneira,

aqueles senhores respeitáveis do comércio marcavam reuniões noturnas para tratar de carnaval e de política (os clubes tiveram papel saliente na campanha da Abolição), mas faziam-nas terminar sempre em jantares, danças e

\footnotetext{
${ }^{7}$ Instrumento musical de sopro da família dos metais.

${ }^{8}$ Os teatros de revista tiveram início, no Brasil, em 1859, no Rio de Janeiro. Influenciadas pelos modelos franceses, essas peças apresentavam uma estrutura fragmentada calcada em um enredo instável, que conectava quadros independentes. $\mathrm{O}$ gênero frequentemente lançava mão da paródia, que servia para desmoralizar e injuriar "algum aspecto, fato, personagem, discurso ou atitude proveniente da cultura erudita ou, em outras palavras, da classe dominante". Informações disponíveis em: http://enciclopedia.itaucultural.org.br/termo614/teatro-de-revista. Acesso em: 20 de fevereiro de 2019.
} 
bebedeiras com as amantes, francesas e mulheres livres em geral (TINHORÃO, 2013: 79).

Ao tomar conhecimento de que, no bairro Cidade Nova, havia uma dança que permitia aos homens "empernar as mulheres com toda a liberdade", os "respeitáveis senhores do comércio" passaram a frequentar os animados bailes da periferia. O ritmo que embalava os movimentos sensuais da dança ficou conhecido como "maxixe", e o gênero, apresentado nos teatros de revista, tornou-se uma atração para a classe média (TINHORÃO, 2013).

O problema inicial foi que o maxixe estava tão intimamente ligado às suas origens negras e mestiças da Cidade Nova e ao seu cultivo suspeito por homens do comércio e mulheres de vida airada, nos clubes carnavalescos, que a simples enunciação do nome maxixe feria a sensibilidade feminina como um desrespeito (TINHORÃO, 2013: 80).

A imagem da figura 1 ilustra os movimentos sensuais que a dança ensejava:

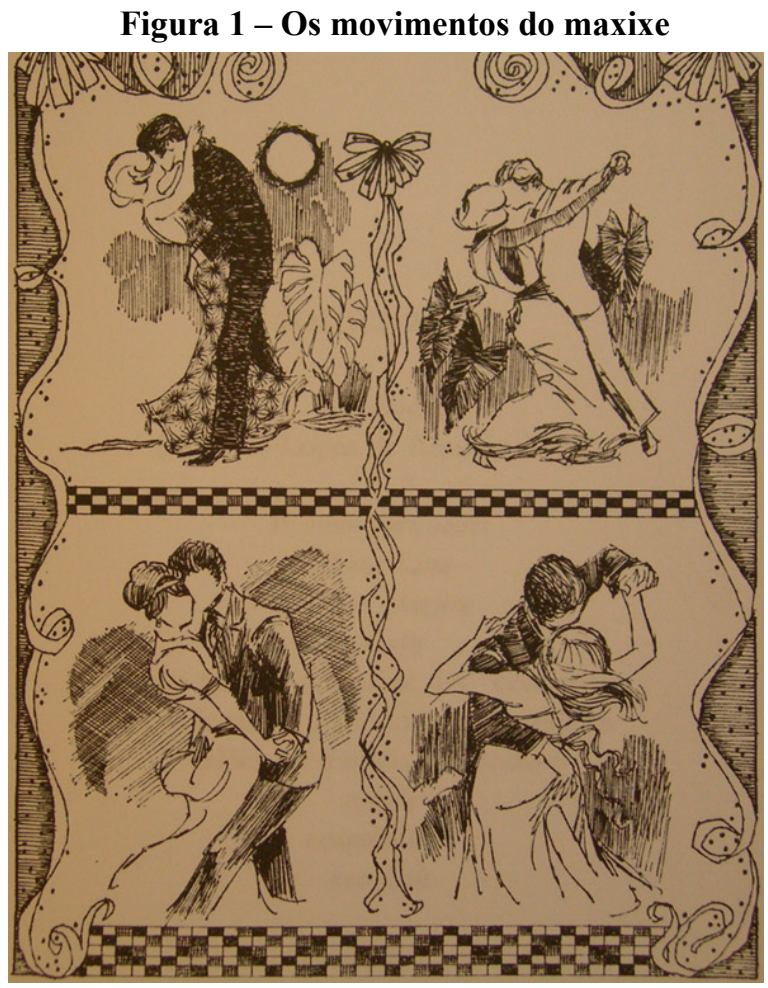

Fonte: EFEGÊ, Jota. Maxixe: a dança excomungada. $2^{\mathrm{a}}$ Edição. Rio de Janeiro: FUNARTE, 2009, p.18.

Portanto, o termo "maxixe" remetia a uma dança despudorada e a certo desrespeito em relação às mulheres, relacionando-se, também, com um fruto com o 
mesmo nome, que provinha de uma planta rasteira, muito comum no bairro Cidade Nova, local de antigos mangues. Como seu local de origem, o nome da dança tinha uma conotação negativa, sendo também usado para referir comportamentos inadequados sob o ângulo moral.

Consequentemente, para que o maxixe fosse introduzido nas classes mais abastadas da sociedade carioca, foram necessárias estratégias que "negociavam" sua apresentação. Os autores de peças de teatro, por exemplo, usavam inicialmente a dança para representar as camadas mais pobres, ou seja, o maxixe fazia parte das "coisas do povo" ". Aos poucos, porém, a dança passou a ser incluída no repertório de peças teatrais e, uma vez aceita, por cerca de quarenta anos, [...] passou a fazer parte de tudo quanto era peça musical do teatro carioca, servindo mesmo de chamariz para o público" 10 (SEVERIANO, 2008: 31-32). A dança do maxixe fez muito sucesso até 1930, período em que foi sendo substituída pelo samba.

\section{Representação do Brasil maxixe em composições do gênero}

O maxixe intitulado "As laranjas da Sabina", publicado por Arthur Azevedo na revista musical $A$ República, foi um dos primeiros sucessos do gênero, no final do século XIX. A peça destaca o caso Sabina, que ocorreu em 1889: alguns estudantes de Medicina organizaram uma passeata a favor da quitandeira Sabina, que vendia suas frutas em frente ao prédio da faculdade, porque ela fora proibida pelo subdelegado da Freguesia de São José de manter seu posto de venda, fato que causou indignação ${ }^{11}$.

\footnotetext{
9 A primeira peça a incluir o gênero foi $O$ caradura, em uma cena cômica, representada pelo ator Vasques, que cantava e dançava no Teatro Santana, em 17 de abril de 1883.

Severiano relata um caso interessante que aconteceu em Paris: o baiano Antônio Lopes de Amorim Diniz, o Duque, chamou a atenção dos franceses em um cabaré ao dançar com a amiga brasileira Maria Lino, que vivia na capital francesa. O casal, que executava muito bem o maxixe, "começou a exibir de forma primorosa (embora bailando ao ritmo de uma polca) o 'parafuso', a 'cobrinha', o 'balão caindo' e outros passos, despertando a atenção dos frequentadores e do dono do cabaré, ávidos de novidades e que jamais haviam visto coreografia semelhante" (SEVERIANO, 2008: 32). Esse espetáculo resultou na contratação do casal pelo estabelecimento.

${ }^{10}$ A não aceitação do gênero por parte da elite carioca levou muitos compositores a "disfarçarem" seus maxixes em outros ritmos, como o tango e o samba. Chiquinha Gonzaga e Sinhô recorreram a essa estratégia para conseguir divulgar suas composições, visto que o maxixe nunca foi, de fato, aceito pela sociedade: "sem jamais ter sido aceito pela classe média, o maxixe praticamente desapareceu na década de 1930. Os motivos foram a chegada de novos ritmos americanos e o crescimento do samba, que afinal também proporciona uma coreografia sensual, porém bem mais comportada. Paradoxalmente, o maxixe canção não deixou um grande legado. Em parte isso se deve ao fato de que, embora muitos tenham composto maxixes, não há a rigor especialistas a se destacarem no setor" (SEVERIANO, 2008: 33).

${ }^{11}$ SEIGEL, Micol; GOMES, Tiago de Melo. Sabina das Laranjas: gênero, raça e nação na trajetória de um símbolo popular, 1889-1930. Revista Brasileira de História. São Paulo, v. 22, nº 43, pp. 171-193, 2002. Disponível em http://www.scielo.br/pdf/rbh/v22n43/10916.pdf. Acesso em 30 dez. 2017.
} 
$\mathrm{Na}$ época, a irreverência da manifestação chamou a atenção da sociedade carioca:

Rompia a marcha uma espécie de estandarte, tendo à lança, uma coroa feita com bananas, chuchus e outros legumes, pendendo da bandeira duas largas fitas, nas quais foram gravadas as seguintes inscrições, em uma: "Ao subdelegado do $1^{\circ}$ distrito da freguesia de S. José oferece a Escola de Medicina"; e em outra: "Ao eliminador das laranjas" (SEIGEL; GOMES, 2002:172).

A letra da música, transcrita a seguir, refere-se explicitamente à ocorrência policial:

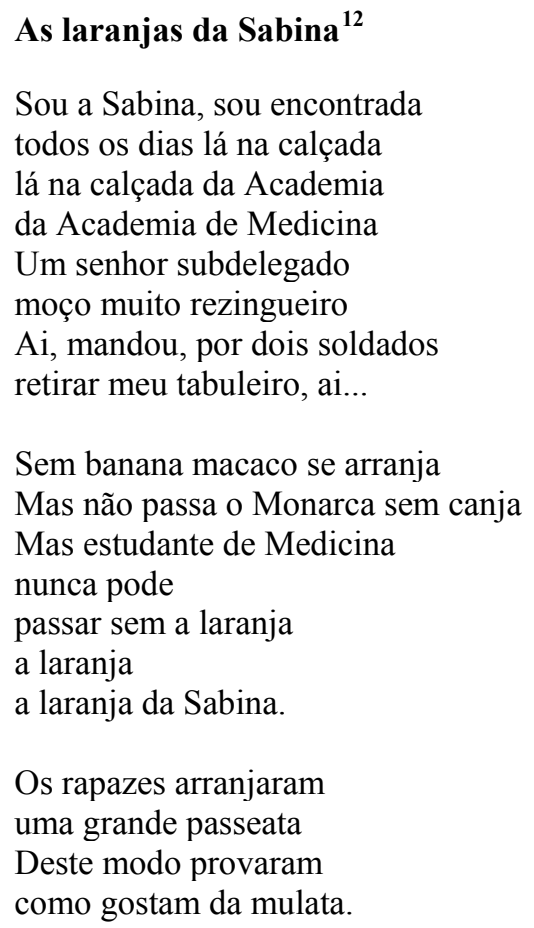

Na primeira estrofe, a situação da quitandeira é apresentada: todos os dias, ela ia até a Faculdade de Medicina vender suas laranjas na calçada do prédio. O último verso da canção faz referência à mulata, permitindo ao receptor da canção compreender que se trata de uma mestiça, que precisa conquistar a freguesia para vender sua mercadoria ${ }^{13}$. $\mathrm{Na}$ segunda estrofe, estabelece-se uma forte oposição entre as condições sociais dos estudantes e as da mulata Sabina: os jovens da elite, brancos, têm acesso à instrução, restrita na época às casses dominantes, compram as frutas da pobre quitandeira, que precisa trabalhar arduamente para conseguir sobreviver.

\footnotetext{
${ }^{12}$ Texto disponível em: https://cifrantiga3.blogspot.com/2013/08/as-laranjas-da-sabina.html. Acesso em: 30 dez. 2017.

13 De acordo com Seigel e Gomes (2002), Sabina era descendente de escravos, possivelmente uma escrava liberta, que, com seu carisma e personalidade forte, alcançou a simpatia dos jovens estudantes.
} 
Apesar de sugerir a forte desigualdade social entre os jovens estudantes e a mulata, a letra revela a simpatia dos rapazes em relação à quitandeira, reforçando a ideia de harmonia entre as raças, fato que pode ser relacionado ao início do reconhecimento do negro e do mestiço como parte integrante do cenário cultural nacional, mencionado por Ortiz (2006).

Além disso, na música, há referência ao Monarca. Segundo Seigel e Gomes (2002), o Imperador costumava comer canja entre os intervalos dos espetáculos dramáticos. O texto ironiza esse aspecto, relacionando-o ao caráter republicano que a manifestação tinha, apesar de não fazer uma crítica direta ao regime monárquico.

Na canção "Vem cá, mulata", cuja parte inicial foi composta por Arquimedes de Oliveira, em 1902, a mulata é convidada a participar do carnaval promovido pelo grupo dos Democráticos Carnavalescos, sociedade social recreativa, fundada em 1867, na cidade do Rio de Janeiro, com o objetivo de promover eventos e festas carnavalescas. Além de se reunir para fins de recreação, seus membros costumavam fazer críticas ao governo vigente ${ }^{14}$.

Embora não haja nenhuma menção a uma possível imagem desprestigiada da mulata, a voz feminina, que pode ser identificada pela alternância de vozes na gravação original $^{15}$, responde que não atenderá ao pedido da voz masculina "Vem cá, mulata". Isso pode ser explicado pelo fato de a segunda estrofe também ser cantada pela voz feminina, que sugere, assim, que ela pertence ao grupo dos Democráticos Carnavalescos, que pode não ser o clube a que a figura masculina pertence. No entanto, a denominação "mulata" expõe atributos da figura feminina e pode ser relacionada ao arquétipo relacionado às mulheres mestiças.

\section{Vem cá, mulata ${ }^{16}$ \\ Vem cá, mulata \\ Não vou lá, não \\ Vem cá, mulata \\ Não vou lá, não \\ Sou Democrata \\ Sou Democrata}

\footnotetext{
${ }^{14}$ Informações retiradas de http://www.clubedosdemocraticos.com.br/32.html. Acesso em 01 jan. 2018.

${ }^{15}$ Disponível em https://www.youtube.com/watch?v=eOgyAy4W8T0. Acesso em 01 jan. 2018.

16 LOPES, Antônio Herculano. Vem cá, mulata. Tempo, v.13 n. 26, Niterói, 2009. Disponível em: http://www.historia.uff.br/tempo/artigos_dossie/v13n26a05.pdf. Acesso em 01 jan. 2018.
} 
Sou Democrata

De coração

De acordo com Gilberto Freyre, a mulata é frequentemente relacionada aos prazeres sexuais, sendo considerada um "caminho de perdição" para os homens brancos: "passa por ser defeito da raça africana, (...) o erotismo, a luxúria, a depravação sexual" (FREYRE, 2004: 398).

Essa conotação sexual, segundo Freyre, está fortemente relacionada à escravidão, sendo imposta pelos colonizadores como extensão do regime escravocrata:

\footnotetext{
É absurdo responsabilizar-se o negro pelo que não foi obra sua nem do índio mas do sistema social e econômico em que funcionaram passiva e mecanicamente. Não há escravidão sem depravação sexual. É da essência mesmo do regime. Em primeiro lugar o próprio interesse econômico favorece a depravação criando nos proprietários de homens imoderado desejo de possuir o maior número possível de crias (FREYRE, 2004: 399).
}

Também Antônio Herculano Lopes (2009) considera que o imaginário a respeito da mulata é consequência da escravidão. No artigo sobre a canção "Vem cá, mulata", em que ele analisa a aparição de atrizes negras ou mestiças nos palcos cariocas, o estudioso deixa claro os arquétipos referentes à mulata e suas diferenças em relação às mulheres brancas:

\footnotetext{
Mas não se pode negar a existência de uma condição estrutural no escravismo que traz embutida a violência mencionada. Mulheres brancas eram para casar, mulheres negras para copular e trabalhar. Filha dessa violência, a mulata passou a significar para alguns intelectuais da virada do século XIX para o XX o símbolo de um pecado, que carregava consigo em sua sensualidade deletéria (LOPES, 2009: 82).
}

Sob esse ângulo, vários sentidos implícitos, relacionados à sensualidade, agregam-se ao termo "mulata". Os versos acrescentados por Manuel Bastos Tigre para a gravação original, em 1906, deixam transparecer, de forma mais clara, a relação da canção com o carnaval, e, consequentemente, da figura da mulata com esse rito:

O Democráticos

Gente jovial

Somos fanáticos

Do carnaval

Do povo vivas

Nós recolhemos

De nós cativas

Almas fazemos.

Ao povo damos sempre alegria

$\mathrm{E}$ batalhamos pela folia 
Não receamos nos sair mal

E letra damos no carnaval.

$\mathrm{Na}$ segunda parte do maxixe, podem ser observados aspectos positivos da mestiçagem, ritualmente celebrados nos grandes eventos como o carnaval (Ortiz, 2006). O ritual carnavalesco é apresentado como representativo do próprio povo brasileiro, que recebe com alegria os grupos que organizam os ritmos e as danças de carnaval.

Já em "Maxixe da Zeferina", o arquétipo da mulata sensual é referido de forma explícita: ela é capaz de enfeitiçar os homens com seu jeito "arteiro". A canção foi composta por Chiquinha Gonzaga em 1911 e faz parte da burleta de costumes, denominada Forrobodó, que estreou no Rio de Janeiro em $1912^{17}$.

Maxixe da Zeferina

Sou mulata brasileira
Sou dengosa feiticeira
A flor do maracujá
A flor do maracujá
Minha mãe foi trepadeira
Arteira e eu arteira
Vivo igualmente a trepar
Vivo igualmente a trepar
Pança com pança
Bate com jeito
Entra na dança
Quebra direito
Quebra direito
Este maxixe
Quase que mata
Não se enrabiche
Pela mulata
Pela mulata

$\mathrm{Na}$ canção, o eu enunciador, que assume papel de sujeito, isto é, a própria mulata reproduz o estereótipo de ser sensual, dengosa e feiticeira, além de sugerir, no quinto ao oitavo versos, que vive da prostituição, como também sua mãe vivera. Ademais, ela não tem nenhum problema em admitir isso, afinal, é "arteira". A menção ao maxixe faz-se pela forma de execução dessa dança: "pança com pança, bate com jeito, quebra direito", manifestando seu caráter envolvente e sedutor.

No final do texto, ainda há uma espécie de aviso: o homem deve ter o cuidado de não se envolver com a mulata. Esse aspecto diz ao respeito ao fato de os homens "de

\footnotetext{
${ }^{17}$ Informações disponíveis em: http://www.chiquinhagonzaga.com/acervo/?musica=forrobodo. Acesso em 30 dez. 2017.

${ }^{18}$ Letra disponível em: https://www.letras.mus.br/chiquinha-gonzaga/555473/. Acesso em: 30 dez. 2017.
} 
família", logo após o surgimento do maxixe, irem ao Bairro Cidade Nova, a fim de dançar o "ritmo proibido", como afirma Tinhorão (2013). Sob esse aspecto, o maxixe era executado por mulheres de classes humildes, sendo indigno das senhoras da classe alta, ou seja, das mulheres "brancas de família". Assim, o maxixe é exclusivo das negras e mulatas, sendo sua dança por mulheres brancas, considerado um desrespeito.

O maxixe "Café paulista, leite mineiro"19, composto por Freire Júnior em 1926, - além de fazer referência à política do Café com Leite, que pressupunha a hegemonia econômica e política dos estados de São Paulo, grande produtor de café, e Minas Gerais, notável produtor de leite - alude à miscigenação racial brasileira, uma vez que compara o leite com a raça branca, e, o café, com a negra:

\section{Café paulista, leite mineiro ${ }^{20}$}

Nosso Mestre Cuca movimentou

O Brasil inteiro,

Cada um estado pra cá mandou

O seu cozinheiro.

Mexeu-se a panela, fez-se a comida

Com perfeição.

Assim foi a boia, bem escolhida

Com precaução

Café paulista,

Leite mineiro,

Nacionalista

Bem brasileiro. Preto com branco,

Café com leite,

Cor democrata.

É preto com branco,

Meu bem, aceite.

Cor da mulata.

O leite é bem grosso, café é forte

Aguenta a mão.

As novas comidas têm que dar sorte

Na situação

Café paulista

Leite mineiro

Nacionalista

Bem brasileiro.

Da mistura do café e do leite, ou seja, do branco e do preto, surge o café com leite, que tem a "cor da mulata". Além disso, essa mistura é "nacionalista" e "bem

${ }^{19}$ Disponível em https://brunohoffmann.wordpress.com/2011/11/23/cafe-paulista-leite-mineiro/. Acesso em 01 jan. 2018.

${ }^{20}$ Letra disponível em: https://cifrantiga.wordpress.com/category/maxixe/. Acesso em: 30 dez. 2017. 
brasileira". Observa-se que, no período em que foi produzida a canção, o discurso da miscigenação é avaliado positivamente e reconhecido como característica cultural do Brasil, isto é, "bem brasileiro", sendo estendido ao sistema econômico proposto por São Paulo e Minas Gerais.

\section{Considerações finais}

Ao analisar as letras dos maxixes, percebe-se que há tanto referências "positivas" quanto "negativas" em relação à miscigenação brasileira. Em "As laranjas da Sabina", pode-se observar a empatia de alguns membros da elite em relação a uma pobre quitandeira, que foi considerada digna de ser representada por eles em um protesto. Por outro lado, o texto remete à forte oposição da condição social do negro em relação ao branco.

Em "Vem cá, mulata", mesmo que não haja menção explícita ao estereótipo da mulher negra, percebe-se que a conotação sensual, a que o termo mulata é relacionado, está presente na canção, uma vez que o vocativo usado pode suscitar significações secundárias. No entanto, também está presente o ritual do carnaval, o qual se relaciona à teoria das três raças no sentido de unificar as diferentes etnias e celebrar a diversidade.

O "Maxixe da Zeferina" ainda coloca a negra e a mestiça em uma posição inferior, visão decorrente do regime escravagista, que presume que a mulata seja o símbolo do pecado, apta a servir aos homens para satisfazer seus desejos sexuais. Além disso, há uma forte vinculação da mulata com o maxixe, que pressupõe movimentos sensuais e envolventes, que, inicialmente, não eram dignos das mulheres brancas e só eram executados pelas mulatas.

Por fim, o maxixe "Café paulista, leite mineiro", concebe a miscigenação como parte do caráter nacional, sendo necessária à formação da identidade, o que o verso "as novas comidas têm que dar sorte" refere.

A partir da análise, é possível verificar que a letra dos maxixes se circunscreve ao universo de representações relacionadas ao mito das três raças, relevante nos estudos sobre a cultura brasileira na virada do século XIX para o século XX, período que coincide com o lançamento das canções. A adesão a uma rede de ideias pode ser explicada por meio do conceito de cultura de Stuart Hall (2016), que a concebe como um "conjunto de significados compartilhados", os quais levam os indivíduos a interpretarem "o mundo de maneira semelhante". Fundamental, nesse processo, é a 
linguagem, uma vez que é "um dos meios através dos quais pensamentos, ideias e sentimentos são representados numa cultura" (HALL, 2016: 18).

Desse modo, observa-se que pontos de vista e valores, vigentes no final do século XIX e início do século XX, povoavam o imagético nacional, constituindo um consistente "sistema de representação", que influenciou práticas e manifestações culturais, entre as quais se situam composições musicais, como o maxixe.

\section{Referências}

BIGNAMI, Rosana. A imagem do Brasil no Turismo: construção, desafios e vantagens competitivas. São Paulo: Editora Aleph, 2005.

BOSI, Alfredo. Plural mas não caótico. In: situações. São Paulo: Ática, 2008, p. 7-14. . Cultura brasileira. Temas e

CAMINHA, Pero Vaz de. A carta de Caminha. Disponível em http://objdigital.bn.br/Acervo_Digital/Livros_eletronicos/carta.pdf. Acesso em: 15 nov. 2017.

CANÇADO, Tânia Lopes. "O "fator atrasado" na música brasileira: evolução, características e interpretação". Per musi, v.2, Belo Horizonte, 2000, p.5-14. Disponível em: http://www.musica.ufmg.br/permusi/port/numeros/02/num02_cap_01.pdf. Acesso em 05 abr. 2019.

DAMATTA, Roberto. O que faz o Brasil, Brasil? Rio de Janeiro: Rocco, 1986.

EFEGÊ, Jota. Maxixe: a dança excomungada. Rio de Janeiro: FUNARTE, 2009.

FREYRE, Gilberto. Casa-grande e senzala: formação da familia brasileira sob o regime da economia patriarcal. 49. ed. São Paulo: Global, 2004.

HALL, Stuart. Cultura e Representação. Tradução: William Oliveira e Daniel Miranda. Rio de Janeiro: PUC-Rio: Apicuri, 2016.

LOPES, Antônio Herculano. "Vem cá, mulata". Tempo, v. 13, n. 26, Niterói, 2009. Disponível em: http://www.historia.uff.br/tempo/artigos_dossie/v13n26a05.pdf. Acesso em 01 jan. 2018.

MARIZ, Vasco. História da música no Brasil. Rio de Janeiro, RJ: Nova Fronteira, 2005.

ORTIZ, Renato. Cultura brasileira e identidade nacional. São Paulo: Editora Brasiliense, 2006.

SEIGEL, Micol; GOMES, Tiago de Melo. "Sabina das Laranjas: gênero, raça e nação na trajetória de um símbolo popular, 1889-1930". Revista Brasileira de História. São 
aulo, v. 22, $\mathrm{n}^{\mathrm{o}}$ 43, pp. 171-193, 2002. Disponível em http://www.scielo.br/pdf/rbh/v22n43/10916.pdf. Acesso em 30 dez. 2017.

SEVERIANO, Jairo. Uma história da música popular brasileira. São Paulo: Editora 34, 2008.

TEATRO de Revista. In: ENCICLOPÉDIA Itaú Cultural de Arte e Cultura Brasileiras. São Paulo: Itaú Cultural, 2019. Disponível em: $<$ http://enciclopedia.itaucultural.org.br/termo614/teatro-de-revista $>$. Acesso em: 20 de fev. 2019. Verbete da Enciclopédia.

TINHORÃO, José Ramos. Pequena história da música popular. São Paulo: Círculo do Livro, 1975.

2013. . Pequena história da música popular. São Paulo: Editora 34,

Recebido 01/07/2019

Aprovado 24/07/2019 